Australian Journal of

Crop Science

AJCS

AJCS 13(12):2003-2014 (2019)

ISSN:1835-2707

doi: 10.21475/ajcs.19.13.12.p2003

\title{
Bacillus spp. as plant growth-promoting bacteria in cotton under greenhouse conditions
}

\author{
Paola Andrea Escobar Diaz ${ }^{1}$, Noemi Carla Baron ${ }^{1}$, Everlon Cid Rigobelo ${ }^{1,2 *}$ \\ ${ }^{1}$ Agricultural and Livestock Microbiology Graduate Program, São Paulo State University (UNESP), School of Agricultural \\ and Veterinarian Sciences, Jaboticabal, Brazil \\ ${ }^{2}$ Rodovia de acesso Professor Paulo Donato Castellane s/n CEP: 14884-900 Jaboticabal Brazil
}

*Corresponding author: everlon.cid@unesp.br

\begin{abstract}
The use of plant growth-promoting bacteria (PGPB) is a promising alternative method to improve plant efficiency in the utilization of chemical fertilizers, enabling a reduction of fertilizer application on crops. This study aimed to evaluate the potential of ten Bacillus strains (eight B. subtilis, one $B$. velezensis and one B. amyloliquefaciens) to promote growth in cotton plants under greenhouse conditions. The experiment was performed in a completely randomized design with 11 treatments and five replicates under greenhouse conditions. The parameters related to plant growth from treatments that received the bacterial isolates were compared to the control. The parameters analyzed were shoot dry matter, root dry matter, total dry matter, plant height, nitrogen content and phosphorus content in soil and in plants. The highest root dry matter was $1.24 \mathrm{~g}$ for the isolate 263 . The total dry matter was $4.0 \mathrm{~g}$ for the isolate 248 and $3.54 \mathrm{~g}$ for the isolate 290 . The highest chlorophyll content was $28 \mu \mathrm{g} / \mathrm{cm}^{2}$ for the isolate 290 . The higher $\mathrm{N}$ content in shoot dry matter was $28 \mathrm{~g}$ of $\mathrm{N}$ for the isolate $290,26 \mathrm{~g}$ for the isolate 248 and $25 \mathrm{~g}$ for the isolate 320 . The improved P efficiency use was $32 \%$ for the isolate $248,28 \%$ for the isolate 188 and $27 \%$ for the isolate 274 . These results strongly confirm that B. subtilis isolates 248,290 and 263 may represent a good alternative as plant growth-promoting endophytes to cotton crops, as they positively affected several parameters evaluated, such as root and shoot dry matter and phosphorus content in the soil. In addition, the parameters evaluated can strongly and positively affect plant yield. However, some isolates of $B$. subtilis did not promote plant growth and most likely failed as bioinoculants. This result shows the importance of properly identifying the isolate for bioinoculation to achieve success in promoting plant growth.
\end{abstract}

Keywords: Bacillus, nitrogen fixation, phosphorus solubilization, chlorophyll content, shoot and root dry matter, height, fertilization efficiency.

Abbreviations: SDM_shoot dry matter; RDM_root dry matter; TDM_total dry matter; CFU_colony forming units; PGPR_plant growth promoting rhizobacteria.

Introduction

The continued use of chemical fertilizers in agriculture has become a serious problem worldwide. The majority of applied agrochemicals persist in the soil for an extended period of time. Tripti et al. (2017) observed that $75-90 \%$ of phosphate fertilization was not properly utilized by plants. This situation leads to the excessive use and application of chemical fertilizers in agricultural fields, causing a deleterious effect on the soil and its microbiota, which results in unproductive soil, as well as social and environmental problems.

The use of plant growth-promoting bacteria is an increasingly popular alternative. These bacteria, found mainly in the rhizosphere, can act as protective agents against pathogens (Adrees et al., 2019), synthesize phytohormones, improve nutrient uptake and induce changes in plant physiology, enabling better flowering processes, germination and plant establishment (Hayat et al., 2010). The positive effects related to the use of these microorganisms as bioinoculants, mainly the increase in the efficiency of nutrient uptake by plants, reduce the production costs and environmental impacts caused by the indiscriminate use of fertilizers in the field (Pedraza et al., 2010).

The genus Bacillus includes more than 60 species of grampositive bacillary bacteria that are able to produce endospores resistant to harmful physical factors, such as high temperatures, radiation and dehydration; additionally, several chemical agents are produced by these bacteria, which favor their use as biofertilizers (Aloo et al., 2019).

Cotton fiber is the most widely used natural textile in the world, and Brazil is the fifth largest producer and the fourth largest exporter of cotton (CONAB, 2017). This crop is 
nutritionally demanding and requires chemical treatment due to its great susceptibility to a wide variety of pests and diseases (Araujo, 2008). Studies such as those by Reva et al. (2004) and Borriss (2011) have demonstrated that the use of $B$. subtilis in cotton can promote plant development and prevent the incidence of diseases.

Many studies have shown the benefits of using Bacillus spp. to increase such parameters as plant development, nutrient availability into soil and nutritional status. However, few studies show that these benefits are variables and depend on isolates. In addition, some isolates carrying characteristics to promote plant growth can harm plant development.

The present study evaluated the use of $B$. subtilis, $B$. velezensis and $B$. amyloliquefaciens as carriers to promote plant growth in cotton plants under greenhouse conditions.

\section{Results and Discussion}

\section{Root and shoot dry matter}

The treatment containing $B$. subtilis isolate 248 presented the highest amount of shoot dry matter (SDM), differing significantly from the control (Fig. 1A). The treatment with $B$. subtilis isolate 263 produced a root dry matter (RDM) amount higher than that of the control (Fig. 1B). For the total dry matter (TDM) amount (Fig. 1C), the treatments with $B$. subtilis isolates 248 and 290 presented significantly higher values than the control.

Direct promotion of plant growth occurs when a bacterium facilitates the acquisition of essential nutrients or modulates the level of hormones within a plant. Nutrient acquisition facilitated by plant growth-promoting rhizobacteria (PGPR) usually includes such elements as nitrogen, phosphorus and iron, which are essential for plant development (Calvo et al., 2017).

Interestingly, eight isolates of $B$. subtilis were inoculated in the plants, but only isolate 248 promoted an increase in shoot dry matter. Isolate 263 promoted an increase in root dry matter, and isolates 248 and 290 promoted an increase in total dry matter. Other B. subtilis isolates, including isolates 274,287 and 309 , significantly reduced the shoot dry matter, isolate 309 reduced the root dry matter, and isolates 274, 287 and 309 reduced the total dry matter compared to the dry matter of the controls (Fig. 1A-1C). These isolates were all identified as $B$. subtilis, and all of them presented important characteristics related to plant growth promotion, such as nitrogen fixation, phosphorus solubilization and IAA production; however, these isolates harmed plant development. Slight genomic differences among these isolates were probably responsible for the differences in plant growth (Bulgarelli et al., 2013). More studies are needed to understand why or how some microorganisms possess the ability to promote plant growth, while others might harm plant development.

Plant height

The treatments resulted in similar plant heights compared to the controls (Fig. 2A). It is possible that the duration of this experiment was not sufficient for these plants to show any differences in height. However, interesting results were observed for the growth pattern of $B$. subtilis isolate 248 . Although no significant difference was found between the height of the treated plants and the height of the controls, at the end of the experiment, it was noted that the plants treated with the $B$. subtilis isolate 248 reached their maximum height faster than the controls; this phenomenon can be observed in the nonlinear regression analysis presented in Fig. 2B.

The results concerning the height of plants were due to a short experimental period of 60 days, suggesting that a longer study period would be ideal to evaluate the increase in growth of plants that received the microbial inoculum.

Phytohormones produced by $B$. subtilis contributed strongly to the enhancement of plant development. Phytohormones are organic substances that can promote, inhibit or modify the growth and development of plants at low concentrations and promote growth with a concomitant increase in nutrient and water uptake (Sureshbabu, Amaresan \& Kumar, 2016).

\section{IAA production}

Interestingly, isolate 188 , which promoted the lowest shoot dry matter, also produced the highest IAA content in the test tube at $15.23 \mu \mathrm{g}$ IAA mL ${ }^{-1}$. Isolate 248 , which promoted the highest root dry matter, did not produce high IAA content (12.51 $\mathrm{\mu g}$ of IAA) in the tube test compared to the other isolates (Table 3 ). Regarding these results, two suggestions could be considered. First, the quantification of IAA in the test tube might not have represented the actual content of IAA produced by these bacteria when interacting with the plants. Second, the high concentration of IAA produced by these bacteria could reduce plant development.

\section{Chlorophyll content}

The initial chlorophyll content 21 days after sowing did not present significant differences with that of the control (Fig. $3 A)$. However, the final chlorophyll content 60 days after sowing revealed significant differences between $B$. subtilis isolate 290 and the control (Fig. 3B).

The nitrogen contents from the shoots of plants treated with isolates 248, 263, 274, 290 and 320 were higher than that of the control (Fig. 4A). In the roots, the nitrogen contents in plants treated with isolates 248,263 and 290 were higher than that of the control (Fig. 4B).

Interestingly, isolate 290 promoted an increase in chlorophyll content and nitrogen content for shoot dry matter. According to Lopes et al. (2014), the chlorophyll content in the leaves is directly related to the nitrogen content in the plant. In Pindi et al. (2014), the plant growth-promoting bacteria promoted an increase in chlorophyll in leaves. The obtained results suggest that the periodic inoculations of isolate 290 at the initial phases of cotton development can increase chlorophyll, improving photosynthetic activity. Moreover, these results strongly relate to the contents of nitrogen and chlorophyll in the plant, since the plants with higher nitrogen contents were 
Table 1. Results of soil analyses.

\begin{tabular}{lllllccccc}
\hline $\mathrm{pH}$ & $\mathrm{OM}$ & $\mathrm{P}(\mathrm{resin})$ & $\mathrm{K}$ & $\mathrm{Ca}$ & $\mathrm{Mg}$ & $\mathrm{H}+\mathrm{Al}$ & $\mathrm{BS}$ & $\mathrm{CEC}$ & $\mathrm{V}$ \\
$\mathrm{CaCl}_{2}$ & $\mathrm{~g} \mathrm{dm}^{-3}$ & $\mathrm{mg} \mathrm{dm}^{-3}$ & $\ldots \ldots \ldots \ldots \ldots \ldots \ldots \mathrm{mmol}_{\mathrm{C}} \mathrm{dm}^{3} \ldots \ldots \ldots \ldots \ldots \ldots$ & $\ldots \ldots \ldots \ldots \ldots \ldots \ldots \ldots \ldots$ & \\
\hline 6,5 & 11 & 20 & 0,7 & 19 & 5 & 17 & 24,4 & 42,8 & 64 \\
\hline
\end{tabular}
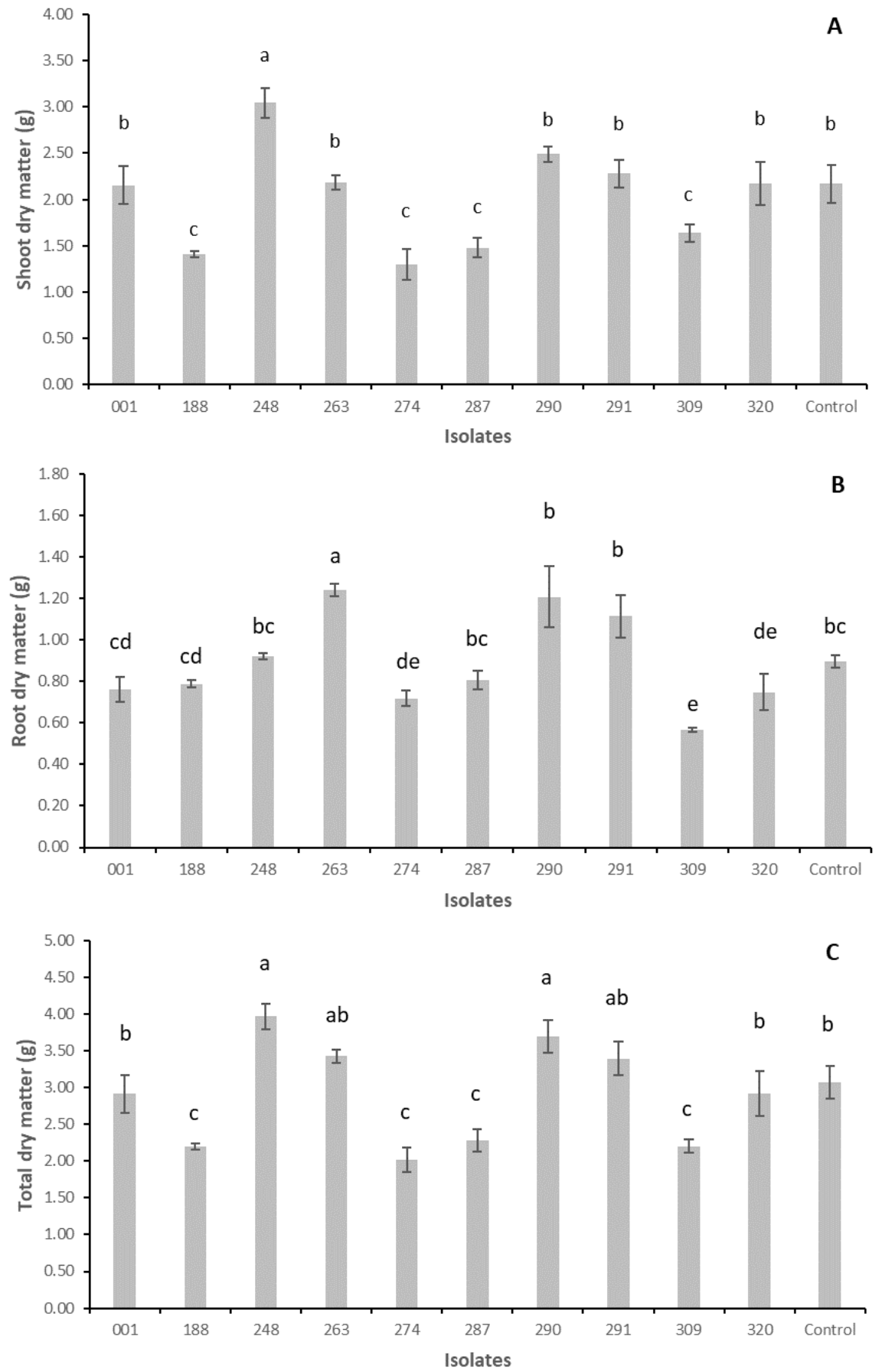

Fig. 1 Means $( \pm S E)$ of shoot dry matter (SDM) (A) root dry matter (RDM) (B) and total dry matter (TDM) (C) of cotton seedlings inoculated with ten isolates of plant growth-promoting bacteria. Different letters indicate significant differences among the treatments according to Duncan's test at $p<0.05$. 
Table 2. Description of isolates used in the study. The left column contains the identifications (ID) of the strains, and the corresponding isolate ID numbers are listed in the right column.

\begin{tabular}{ll}
\hline Strain ID & Isolate ID \\
\hline Bacillus amyloliquefaciens & 001 \\
Bacillus velezensis & 188 \\
Bacillus subtilis & 248 \\
Bacillus subtilis & 263 \\
Bacillus subtilis & 274 \\
Bacillus subtilis & 287 \\
Bacillus subtilis & 290 \\
Bacillus subtilis & 291 \\
Bacillus subtilis & 309 \\
Bacillus subtilis & 320 \\
CONTROL & - \\
\hline
\end{tabular}
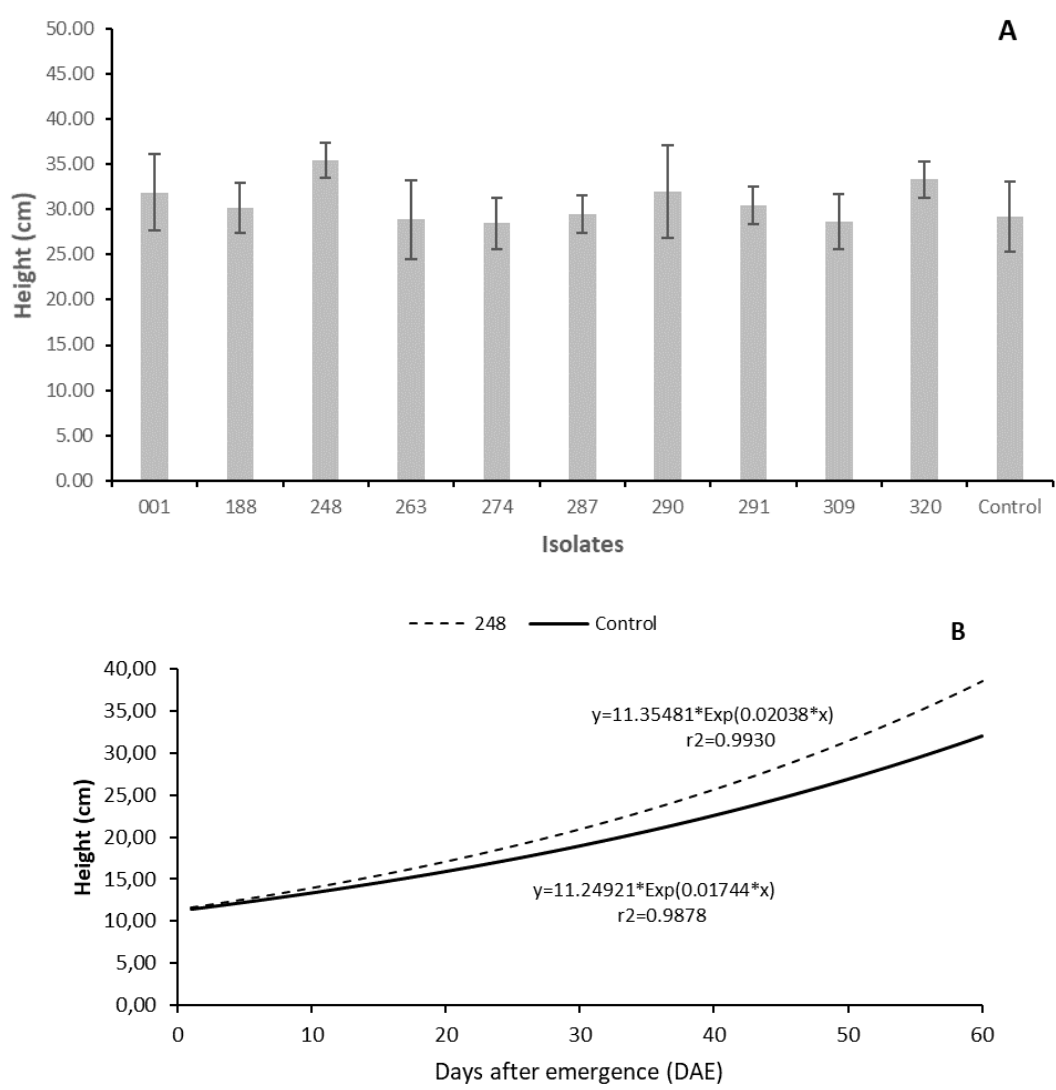

Fig. 2. Means $( \pm S E)$ of cotton seedlings inoculated with 10 isolates of growth-promoting bacteria 60 days after emergence $(A)$ and nonlinear regression analysis of seedling heights of cotton plants inoculated with Bacillus subtilis isolate 248 (B). The absence of letters indicates that there were no significant differences among treatments according to Duncan's test at $p<0.05$. 
Table 3. Indole acetic acid amount produced by each B. subtilis, B. velezensis and B. amyloliquefaciens bacterial isolate.

\begin{tabular}{ll} 
ISOLATE CODE & $\mu \mathrm{g} I \mathrm{AA} / \mathrm{mL}$ \\
\hline 001 & 13.45 \\
188 & 15.23 \\
248 & 12.51 \\
263 & 11.32 \\
274 & 12.44 \\
275 & 11.54 \\
287 & 13.37 \\
290 & 13.02 \\
291 & 11.51 \\
309 & 11.80 \\
320 & 12.41 \\
\hline
\end{tabular}
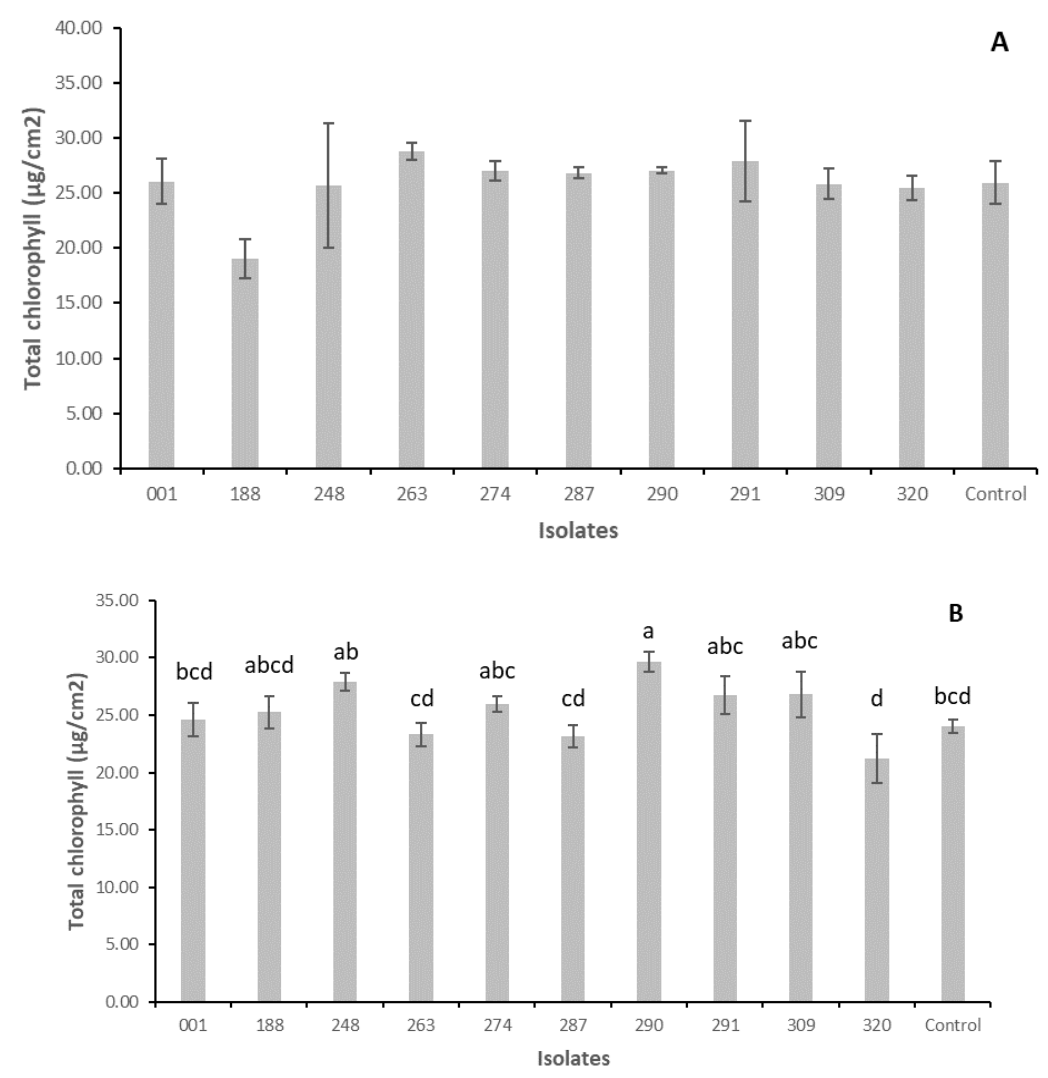

Fig. 3 Means $( \pm S E)$ of initial chlorophyll content in cotton leaves 21 days after inoculation $(A)$ and final chlorophyll content in cotton leaves 60 days after inoculation (B) with ten isolates of growth-promoting bacteria. The absence of letters indicates that there were no significant differences among treatments (A). Different letters indicate significant differences among treatments (B) Duncan's test at $\mathrm{p}<0.05$. 

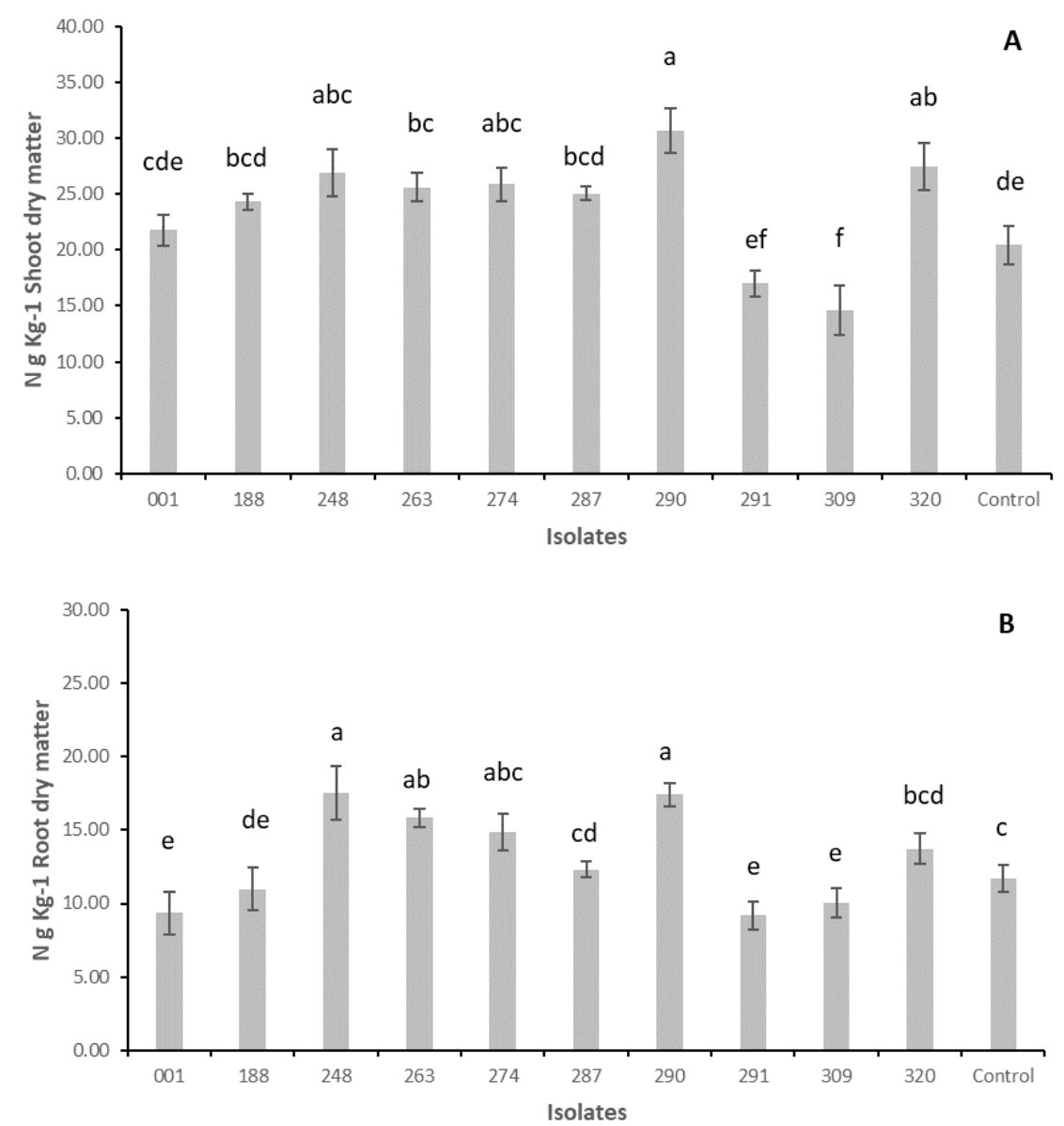

Fig. 4 Means $( \pm S E)$ of nitrogen in the shoots $(A)$ and roots $(B)$ of cotton seedlings inoculated with ten isolates of Bacillus. Different letters indicate significant differences among treatments Duncan's test at $p<0.05$.

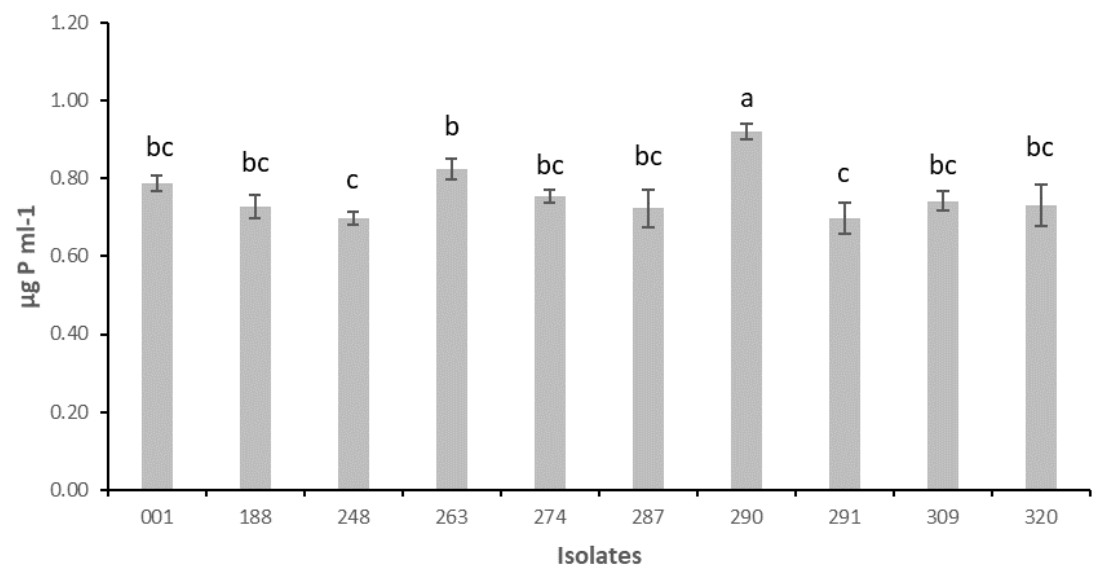

Fig 5. Means $( \pm \mathrm{SE})$ in vitro solubilization of phosphorus of 10 isolates of Bacillus on calcium phosphate. Different letters indicate significant differences among treatments Duncan's test at $p<0.05$. 

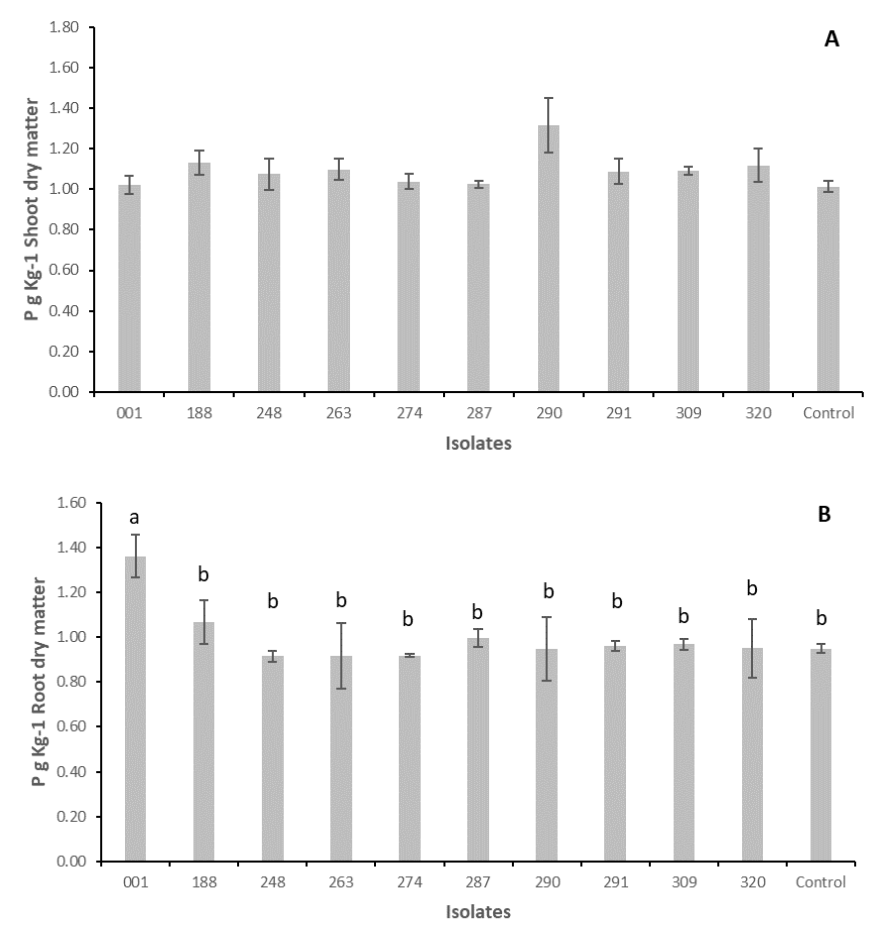

Fig. 6. Means $( \pm S E)$ of phosphorus in the shoots $(A)$ and roots $(B)$ of cotton seedlings inoculated with ten isolates of growth-promoting bacteria. The absence of letters indicates that there were no significant differences among treatments $(A)$. Different letters indicate significant differences among treatments (B) Duncan test at $p<0.05$
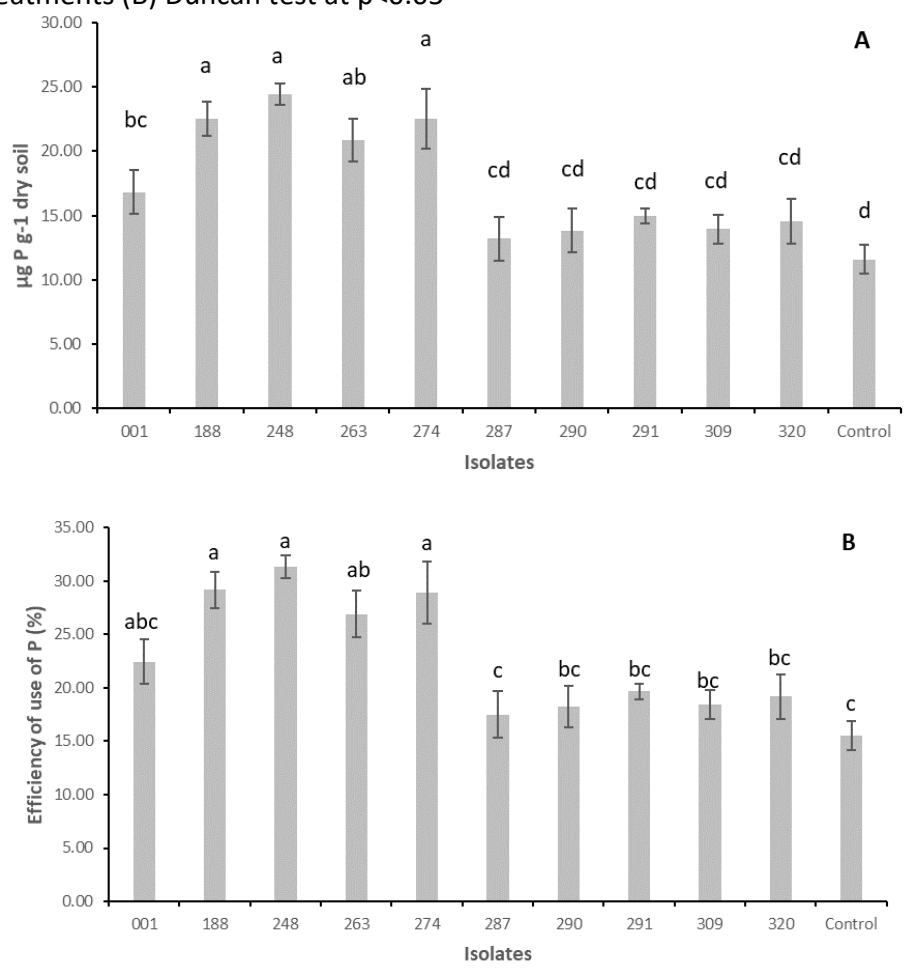

Fig 7. Means $( \pm \mathrm{SE})$ of soluble phosphorus content in soil inoculated with 10 isolates of Bacillus (A) and $\mathrm{P}$ use efficiency (\%) of plants inoculated with 10 isolates (B). Different letters indicate significant differences among treatments Duncan's test at $p<0.05$. 

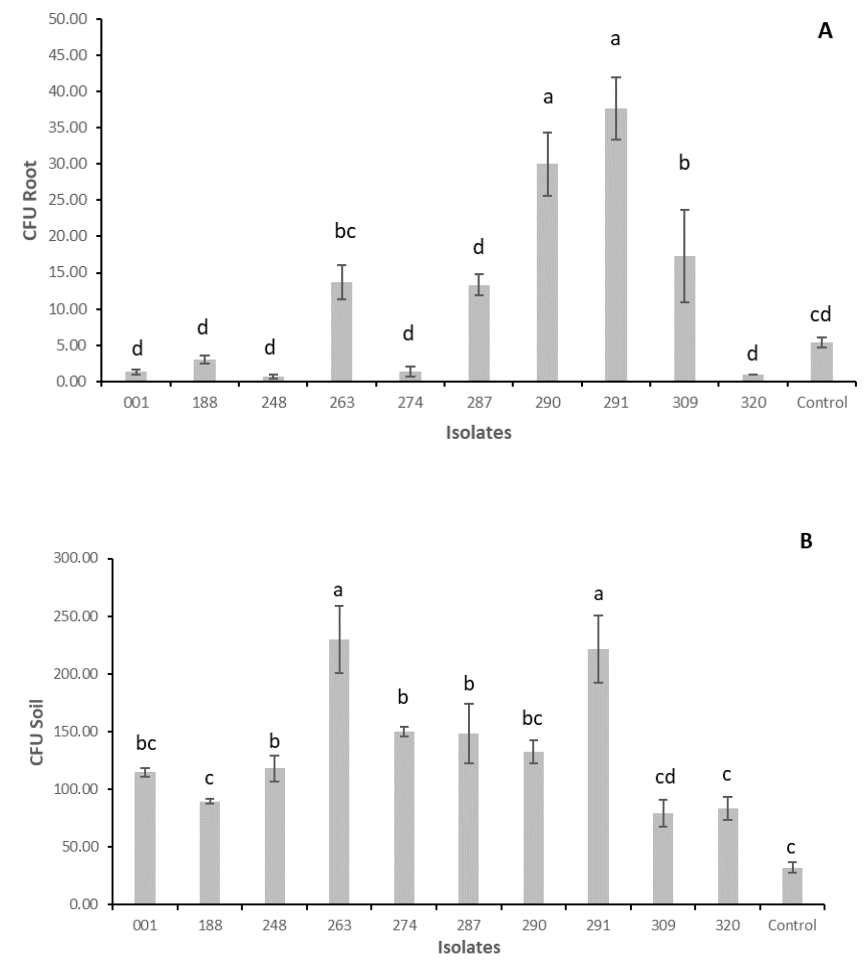

Fig 8. Means $( \pm S E)$ of colony forming units (CFUs) in roots of cotton seedlings (A) and soil $(B)$ inoculated with ten isolates of Bacillus. Different letters indicate significant differences among treatments Duncan's test at $p<0.05$.

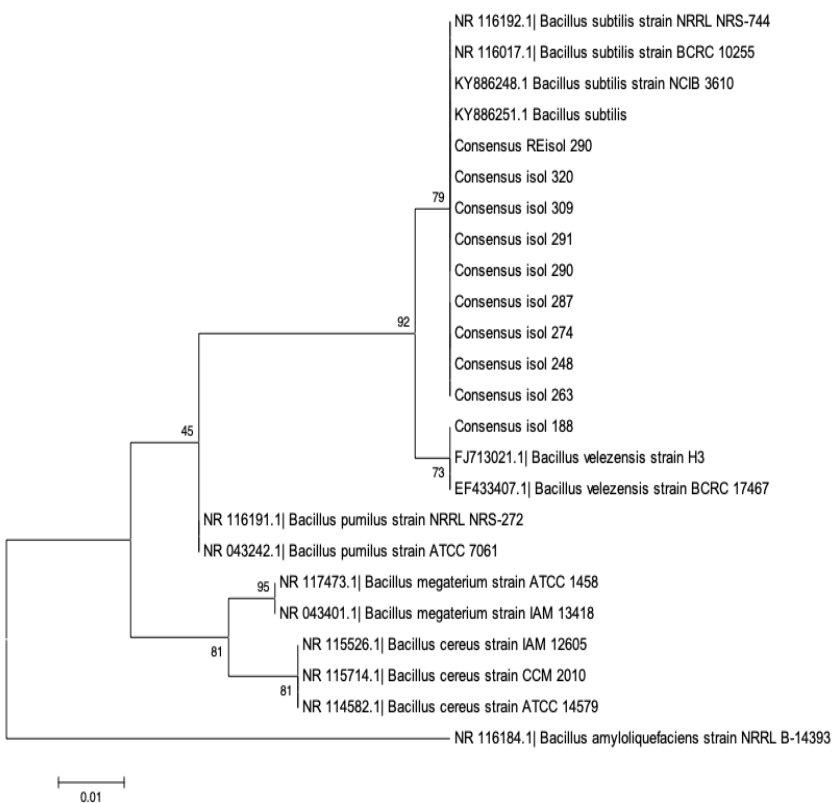

Fig 9. 16S rDNA phylogenetic analysis of Bacillus isolates used as treatments and reisolated from the soil in the greenhouse. The phylogenetic tree construction was based on the maximum likelihood method with the evolutionary distances calculated according to the Kimura-2 parameter model. Bootstrap values are presented as a percentage for 1000 repetitions. Number codes before the species names refer to their accession number in GenBank (NCBI). 
treated with isolate 290 , the same isolate that promoted the higher chlorophyll content (Fig. 4A).

A high content of nitrogen in the shoots, as observed for isolates 290, 248, 320 and 274, indicates that the isolates interacted with the soil microbiota and colonized the rhizosphere, making some metabolites available to the plants. Some studies have also shown that the inoculation of Bacillus spp., Azotobacter and Azospirillum in cotton and palm trees contributed to a significant increase in nitrogen levels (Guzmán et al., 2012).

However, isolates 309, 291 and 001 reduced the nitrogen content in both the shoots and roots compared to that of the control (Fig. 4). It is important to note that the selection of bacteria to promote plant growth is critical because the plant response is variable depending on the bacterial isolate, plant genotype and assay conditions, even when using the same bacterial species (Bulgarelli et al., 2013).

\section{Phosphorus solubilizing}

B. subtilis isolate 290 solubilized the largest amount of phosphorus in the liquid medium assay compared to other Bacillus isolates (Fig. 5). Although eight of the ten isolates were of the species $B$. subtilis, the results showed that different strains presented different abilities in their efficiency to solubilize this source of phosphorus under laboratory conditions. These variations in phosphorus solubilization by the same bacterial strains were already reported by Nahas (1996).

Regarding the phosphorus content in the shoot, no significant differences were found between the treatments and the controls (Fig. 6A). However, there was a significant difference in the phosphorus content in the roots of plants treated with B. amyloliquefaciens isolate 001 (Fig. 6B).

Similar studies with bacterial inoculation of Bacillus demonstrated that these microorganisms can solubilize phosphate and increase the availability of this nutrient for absorption by plants. Several genes involved in phosphorus solubilization have been described in Bacillus species (Lastochkina et al., 2017).

Bacteria of the Bacillus genus can solubilize phosphorus through the release of organic acids and phosphatase enzymes that are secreted into the soil (Patiño-Torres and SanclementeReyes, 2014). These molecules transform unavailable forms of organic and inorganic phosphate to readily available forms for plants, and this phosphorus can be stored in the roots (Kpomblekou-A and Tabatabai, 1994). When this nutrient is needed, it can be transported to the shoot, where it remains available for metabolic reactions of the plant. Interestingly, isolates 188, 248, 263 and 274 increased the phosphorus available in the soil compared to the soil of the control (Fig. 7A). However, no isolate increased the phosphorus content in shoot dry matter (Fig. 6A), and only B. amyloliquefaciens was able to increase the phosphorus content in the roots (Fig. 6B). Isolate 290, which presented the highest value for phosphorus solubilization under laboratory conditions, did not promote the highest phosphorus availability in the soil. Therefore, it is possible to conclude that the data regarding phosphorus solubilization from the ten isolates in the laboratory were important; however, the isolates need to be studied in soil conditions. These differences in the results concerning the phosphorus in test tube conditions and in soil conditions could have occurred due to soil type, plant age, plant genotype and microbial species in the soil, which could affect the phosphorus solubilization process.

The use of $B$. subtilis strains as bioinoculants is not a substitute for fertilization. However, the results of this study suggest that the use of isolates 188, 248, 263 and 274 increased the absorption efficiency of phosphorus from fertilization, which could be combined in the future to lower fertilization losses in cotton crops.

By analyzing the phosphorus content in the shoot (Fig. 6A) and root (Fig. 6B) dry matter and phosphorus in the soil (Fig. 7A), it was possible to determine the $P$ use efficiency and to determine the capacity for $P$ uptake with phosphorus fertilization up to 60 days after sowing.

The $P$ use efficiency was significantly higher in the treatments that received the microbial inoculum, including isolates 188 , 248, 263 and 274, compared to that in the control (Fig. 7B). Interestingly, these treatments also presented high phosphorus contents in the soil (Fig. 7A). Melchiori et al. (2004) reported that the $P$ use efficiency may improve root dry matter production in plants depending on the amount of $P$ absorbed. The efficiency of $\mathrm{P}$ absorption is related to the kind of fertilizer used in soil and the root density of the plant due to the importance of these factors for $\mathrm{P}$ absorption (Jacoby et al., 2017).

In this study, a relationship was observed between root dry matter production and $P$ use efficiency (Fig. 1B) in plants treated with $B$. subtilis isolate 263 . The $P$ absorption in the plants that received $B$. subtilis was higher than in the control. This result might be due to root distribution in the soil.

In the roots, the plants inoculated with isolates 290 and 291 presented a higher number of CFUs. ${ }^{-1}$ (Fig. 8A), while in the soil, the treatments inoculated with isolates 263 and 291 presented a higher number of CFUs. ${ }^{-1}$ compared to the number of CFUs. $\mathrm{g}^{-1}$ in the controls (Fig. 8B). These results can be attributed to the success of these $B$. subtilis isolates $(263$, 290 and 291) in associating with soil microbiota and roots, which allowed a greater interaction with cotton plants. Some studies have demonstrated that $B$. subtilis affects root and shoot growth. Moreover, B. subtilis can act to control phytopathogens due to its ability to colonize plant tissues, live as epiphytes, endophytes or in the rhizosphere, and provide a broad use spectrum in agriculture (Lanna Filho et al., 2010).

Previously, all of the isolates tested in this study had the $16 \mathrm{~S}$ ribosomal DNA region sequenced for identification. These sequences were aligned with other sequences from the same species and others from related species. At the end of this experiment, root samples from each treatment were collected, and the endophytic bacteria from each root were reisolated. Then, all of the bacteria isolated from each plant from each treatment were sequenced. The phylogenetic tree was elaborated with the bacterial sequences found. The results are shown in Fig. 9.

The phylogeneti c tree allowed us to confirm the identification of the isolates recovered from each root showing the capacity for endophytic colonization of each isolate. 
Materials and Methods

Plant materials

\section{Experiment location}

The experiment was performed under greenhouse conditions, and the chemical and microbiological analyses were carried out at the Laboratory of Soil Microbiology of the Department of Plant Production, School of Agricultural and Veterinarian Sciences, São Paulo State University, UNESP, Jaboticabal, Brazil.

Soil

The soil used in the experiment was oxisol. The soil chemical analysis is presented in Table 1.

The soil was sifted and used to fill five-liter pots. Fertilization was performed according to soil analysis and the nutritional requirements of cotton crop. Fertilizer consisted of $3.34 \mathrm{~g}$ of urea (nitrogen), $81.67 \mathrm{~g}$ of Super Simple (phosphorus). 0.3379 $\mathrm{g}$ of $\mathrm{KCl}$ (potassium), $1.94 \mathrm{~g}$ of $\mathrm{ZnSO}_{4} 7 \mathrm{H}_{2} \mathrm{O}$ (zinc) and $0.0070 \mathrm{~g}$ of $\mathrm{H}_{3} \mathrm{BO}_{3}$ (boron) applied to each pot for nutrient supplementation before sowing. Humidity was maintained at approximately $70 \%$ of the field capacity with daily irrigation. Fertilization was equivalent to $350 \mathrm{~kg} \mathrm{ha}^{-1}$.

\section{Sowing}

Four cotton seeds (Gossypium hirsutum - IMA15675 $\mathrm{B}_{2} \mathrm{RF}$ ) were sown in each pot. Fifteen days after the emergence of the seedlings, thinning was performed, and only one plant was left per pot.

\section{Microorganisms and inocula preparation}

The endophytic microorganisms used in this study were previously isolated from corn crop and belonged to the culture collection of the Laboratory of Soil Microbiology.

Ten bacterial strains were selected for this experiment and are shown in Table 2. These bacteria were selected based on a previous study (Milani, 2017), which demonstrated that these isolates presented interesting characteristics for plant growth promotion, such as phosphorus solubilization, nitrogen fixation, and indole acetic acid (IAA) production.

Each strain was cultured in a $125 \mathrm{~mL}$ Erlenmeyer flask containing $60 \mathrm{~mL}$ of nutrient broth for 24 hours at $30 \circ \mathrm{C}$ in a microbiological incubator. After incubation, the suspensions were standardized and read with a spectrophotometer at 630 $\mathrm{nm}$ to determine the concentration of the inoculum (Kloepper et al., 1989). The suspensions were inoculated in solid medium (nutrient agar) and incubated for 24 hours to count and check the purity of the isolates. Then, using the same methods, new suspensions were prepared using colonies from the plates as inoculum, and the concentration was adjusted to $1 \times 10^{9}$ colony-forming units per milliliter (CFU. $\mathrm{mL}^{-1}$ ).

\section{Inoculation}

Cotton seeds of IMA $15675 \quad B_{2} R F$ were inoculated by immersion in the bacterial suspensions, which were maintained under agitation on a rotatory shaker at $130 \mathrm{rpm}$ for $30 \mathrm{~min}$. After this period, the seeds were removed from the suspensions and sown in pots containing soil in the greenhouse.

After emergence, the seedlings were inoculated every eight days with $10 \mathrm{~mL}$ of a bacterial suspension containing $1 \times 10^{9}$ CFU $\mathrm{ml}^{-1}$. Inoculation was performed at the base of the aerial part of the plant to evaluate the efficiency of colonization and plant growth promotion.

\section{Experimental design and statistical analysis}

The experiment was carried out using a completely randomized design with 11 treatments and five repetitions for a total of 55 pots. Data normality was determined by ShapiroWilk's test, and the homogeneity of variances (Levene's test) was tested for each evaluated parameter. Data were submitted to an analysis of variance ( $F$ test), and the means were compared by Duncan's test $(P \leq 0.05$ Evaluated parameters

\section{Plant height}

Plant height was evaluated to verify the correlation between plant growth promotion and inoculation with Bacillus spp. Height was determined using a ruler graduated in centimeters measuring the distance from near the ground until the apex of the plant. Stalk diameter was measured with the aid of a digital pachymeter. Measurements were taken weekly, and a total of eight measurements were performed throughout the experiment.

\section{Shoot and root dry matter}

At the end of the experiment, all plants were collected, and shoots and roots were separated, washed in running water and placed into paper bags. The samples were dried in an oven with air circulation at $65^{\circ} \mathrm{C}$ for 72 hours until a constant weight was reached. Dry matter was then determined using an analytical balance.

\section{Chlorophyll content in the leaves}

The chlorophyll content was determined using dimethylformamide. Spectrophotometer readings at 480, 647 and $664 \mathrm{~nm}$ were performed according to the methodology proposed by Wellburn (1994). Three plants were randomly chosen from each treatment for the analysis. Samples were collected from the third leaf at two-thirds the height of the plant, as measured from the base and at $1 \mathrm{~cm}$ from the leaf margin.

\section{Selection of IAA-producing epiphytic and endophytic bacteria}

The production of indole acetic acid (IAA) was measured using the methodology of Kuss et al. (2007) with modifications. 
Each bacterial isolate was applied in $20 \mathrm{~mL}$ of dextrose yeast glucose sucrose (DYGS) medium containing $2 \mathrm{~g}^{-1} \mathrm{~L}^{-1}$ glucose, 1.5 g. $\mathrm{L}^{-1}$ peptone, $2 \mathrm{~g}$. $\mathrm{L}^{-1}$ yeast extract, $0.5 \mathrm{~g}$. $\mathrm{L}^{-1}$ potassium dihydrogen phosphate, and $0.5 \mathrm{~g}$. $\mathrm{L}^{-1}$ magnesium sulfate heptahydrate (Rodriguez Neto et al., 1986), supplemented with $5 \mathrm{mM}$ L-tryptophan, and incubated for 48 hours at $28^{\circ} \mathrm{C}$ under constant shaking at $120 \mathrm{rpm}$ and in the absence of light (Andrade, 2012). Then, $5 \mathrm{ml}$ of each culture was centrifuged at $10,000 \mathrm{rpm}$ for $10 \mathrm{~min}$, and $2 \mathrm{ml}$ of the supernatant was transferred to a test tube containing $2 \mathrm{ml}$ of Salkowski reagent $2 \%(\mathrm{w} / \mathrm{v})(0.5 \mathrm{M} \mathrm{FeCl} 3$ in $35 \%$ perchloric acid) (Sarwar and Kremer, 1995) and incubated in the absence of light for 30 $\min$.

The production of IAA was qualitatively determined by the red coloration of the solution contained in the test tube. For the quantitative evaluation of the hormone, a spectrophotometer with a wavelength of $530 \mathrm{~nm}$ was used. The concentration was obtained by comparison with noninoculated sterile culture medium with known concentrations of commercial IAA $(0,10,20,40,60,70,80,90$, 100,110 and $120 \mu \mathrm{g} I \mathrm{AA} /$ tube). For each concentration, a duplicate was made, which was normalized by the standard curve resulting in the equation $y=0.0156 x-0.0832(R 2=$ 0.9965), where " $x$ " represents the concentration of IAA ( $\mu \mathrm{g}$ IAA / tube) and " $Y$ "is the mean absorbance observed with the spectrophotometer.

\section{Nitrogen content in shoots and roots}

Nitrogen content was determined by the Kjeldahl method proposed by Bremner (1996); Mulvaney (1996) and modified according to Bezerra Neto and Barreto (2011) with digestion, distillation and titration of the samples.

\section{Phosphorus content in shoots and roots}

The phosphorus content was determined according to the methodology proposed by Haag et al., (1975) with sulfuric digestion of plant material followed by the methods of Bezerra Neto and Barreto (2011).

\section{Soil sample preparation}

Soil samples were split into two subsamples with approximately $100 \mathrm{~g}$ of soil in each. The first sample was sifted and dried at room temperature and then used for chemical analysis, while the second sample was kept refrigerated for use in the microbiological analysis.

\section{Soluble phosphorus in soil}

For this analysis, the phosphorus solubility in bicarbonate methodology of Watanabe and Olsen (1965) was employed.

\section{Isolation and counting of Bacillus spp. in soil and roots}

The number of colony-forming units (CFUs) was estimated by serial dilution (Wollum, 1982). Bacillus spp. isolation was performed following a selective isolation method based on thermal shock proposed by Rothfuss et al. (1997) and Vieira and Nahas (2000).

\section{Insoluble phosphate solubilization in liquid medium}

Determination of solubilization capacity of the strains was carried out following the method described by Ames (1966).

16S DNA extraction, amplification and sequencing

The strains used in this study had the 16S DNA region pr eviously sequenced by Milani (2017).

To confirm that the obtained results were due to the action of the inoculated strains, all of the roots were sampled, and the bacterial colonies from the isolation performed after the experiment were characterized again. Genomic DNA was extracted using the Quick-DNA Universal Kit (Zymo Research) following the manufacturer's instructions.

By using the primers P027F (5'-GAGAGTTTGATCCTGGCTAG-3') and 1378R (5'-CGGTGTGTACSSGGCCCGGGAACG-3'), 16S ribosomal DNA was amplified by polymerase chain reaction (PCR) with the following amplification program: 95으 for $2 \mathrm{~min}$ followed by 25 cycles of denaturation at $95{ }^{\circ} \mathrm{C}$ for $30 \mathrm{~s}$, annealing at $63^{\circ} \mathrm{C}$ for $1 \mathrm{~min}$ and extension at $72^{\circ} \mathrm{C}$ for $1 \mathrm{~min}$, and a final extension at $72^{\circ} \mathrm{C}$ for $7 \mathrm{~min}$. The PCR products were purified and sequenced in an automated DNA ABI3730 sequencer using the primers P027F and $1378 \mathrm{R}$.

The sequences were aligned and edited using the software BioEdit 7.0.5.3. (Hall, 1999) and compared to the sequences from GenBank at the NCBI (National Center for Biotechnology Information). Phylogenetic analyses were performed using the software MEGA 6.0 (Tamura et al., 2013).

\section{Use efficiency of $P$}

The efficiency of $P$ use was calculated by multiplying the total amount dry matter by the phosphorus content of the roots and shoots, which equaled the total $P$ content extracted from the soil by the plants. Then, the percentage of the total phosphorus content in the plants in each treatment was calculated in relation to the $\mathrm{P}$ added through the fertilization of the soil.

\section{Conclusion}

The results strongly confirm that $B$. subtilis isolates 248,290 and 263 can be a good alternative as plant growth-promoting endophytic bacteria for cotton crops, and they positively affected several parameters evaluated, such as root and shoot dry matter and phosphorus content in the soil. However, some B. subtilis isolates did not promote plant growth, and if they had been used as bioinoculants, they would probably have failed. This result shows the importance of identifying and understanding the bioinoculant isolate to achieve success in promoting plant growth.

\section{Acknowledgments}

The authors are grateful to CAPES for providing scholarships, FAPESP for providing financial support (Process Number 
2014/18313-8) and Dr. Oniel Jeremias Aguirre Gil for offering suggestions and assisting with data analysis.

\section{References}

Adrees HM, Haider S, Anjum T, Akram, W (2019) Inducing systemic resistance in cotton plants against charcoal root rot pathogen using indigenous rhizospheric bacterial strains and chemical elicitors. Crop Protec. 115: 75-83.

Aloo BN, Makumba BA, Mbegaa ER (2019) The potential of Bacilli rhizobacteria for sustainable crop production and environmental sustainability. Microbiol Res. 219: 26-39.

Ames BN (1966) Assay of inorganic phosphate, total phosphate and phosphatases. Methods Enzymol. 8:115-118.

Araujo FF (2008) Seed inoculation with Bacillus subtilis formulated with oyster meal and growth of corn soybean and cotton. Ciênc E Agrotecnologia. 32:456-462.

Bulgarelli D, Schlaeppi K, Spaepen S, Ver Loren van Themaat E, Schulze-Lefert P (2013) Structure and functions of the bacterial microbiota of plants. Annu Rev Plant Biol. 64:807-838.

Bezerra Neto E, Barreto LP (2011) Análises químicas e bioquímicas em plantas. Editora Universitária da UFRPE, Recife.

Borriss R (2011) Use of plant-associated Bacillus strains as biofertilizers and biocontrol agents in agriculture. In: Maheshwari DK (Ed) bacteria in agrobiology: plant growth responses. Springer, Berlin, Heidelberg.

Bremner JM (1996) Nitrogen-Total. In: Sparks DL, Page AL, Helmke PA, Loeppert RH (eds) Methods of Soil Analysis Part 3-Chemical Methods, SSSA Book Ser. 5.3. SSSA, ASA, Madison, WI.

Calvo P, Watts DB, Kloepper JW, Torbert HA (2017) Effect of microbial-based inoculants on nutrient concentrations and early root morphology of corn (Zea mays). J Plant Nutrit Soil Sci. 180:56-70.

CONAB (2017) Acompanhamento da safra Brasileira de graõs (Monitoramento Agricola/Safra 2016/17 No N9): Safra 2016/17. Companhia Nacional de Abastecimiento, Brasilia.

Guzmán A, Obando M, Rivera D, Bonilla R (2012) Selección y caracterización de rizobacterias promotoras de crecimiento vegetal (RPCV) asociadas al cultivo de algodón (Gossypium hirsutum). Rev Colomb Biotecnol. 14:182-190.

Haag HP, Sarruge JR, de Oliveira GD, Dechen AR (1975) Nutrição mineral do cajueiro (Anacardium occidentale L): I-deficiência dos macronutrientes-nota prévia. An Esc Super Agric Luiz Queiroz. 32:185-190.

Hayat R, Ali S, Amara U, Khalid R, Ahmed I (2010) Soil beneficial bacteria and their role in plant growth promotion: a review. Ann Microbiol. 60:579-598.

Jacoby RM, Peukert A, Succurro A, Koprivova A, Kopriva S (2017) The role of soil microorganisms in plant mineral nutritioncurrent knowledge and future directions. Frontiers in Plant Sci. 8:1617.

Khalid A, Arshad M, Shaharoona B, Mahmood T (2009) Plant Growth Promoting Rhizobacteria and Sustainable Agriculture In: Khan MS, Zaidi A, Musarrat J (eds) Microbial Strategies for Crop Improvement. Springer, Berlin, Heidelberg.

Kuss AV, Kuss VV, Lovato T, Flôres ML (2007) Nitrogen fixation and in vitro production of indolacetic acid by endophytic diazotrophic bacteria. Pesq Agropec Bras. 42: 1459 - 1465.
Kloepper JW, Lifshitz R, Zablotowicz RM (1989) Free-living bacterial inocula for enhancing crop productivity. Trends Biotechnol. 7:39-44.

Kpomblekou-A K, Tabatabai M (1994) Effect of organic acids on release of phosphorus from phosphate rocks. Soil Sci. 158:442453.

Lanna Filho R, Ferro HM, de Pinho RSC (2010) Controle biológico mediado por Bacillus subtilis. Rev Trópica Ciênc Agrár E Biológicas. 4:12-20.

Lastochkina OL, Pusenkova R, Yuldashev R, Babaev M, Garipova S, Blagova D, Khairullin R, Aliniaeifard S (2017). Effects of Bacillus subtilis on some physiological and biochemical parameters of Triticum aestivum L. (wheat) under salinity. Plant Physiol Biochem. 121: 80-88.

López DBS, Hoyos AMG, Perdomo FAR, Buitrago RRB (2014) Efecto de rizobacterias promotoras de crecimiento vegetal solubilizadoras de fosfato en Lactuca sativa cultivar White Boston. Rev Colomb Biotecnol. 16:122-128.

Milani RM (2017) Diversidade de bactérias epífitas e endofíticas da cultura do milho. Universidade Estadual Paulista "Julho Mesquita Filho", Jaboticabal-Brazil.

Nahas E (1996) Factors determining rock phosphate solubilization by microorganisms isolated from soil. World J Microbiol Biotechnol. 12:567-572.

Patiño-Torres CO, Sanclemente-Reyes OE (2014) Los microorganismos solubilizadores de fósforo (MSF): una alternativa biotecnológica para una agricultura sostenible. Entramado. 10:288-297.

Pedraza RO, Teixeira KRS, Scavino AF, Salamone IG, Baca BE, Azcón R, Baldani VLD, Bonilla R (2010) Microorganismos que mejoran el crecimiento de las plantas y la calidad de los suelos. Revisión Corpoica Cienc Tecnol Agropecu. 11:155-164.

Pindi PK, Sultana T, Vootla PK (2014) Plant growth regulation of Btcotton through Bacillus species. 3 Biotech. 4:305-315.

Reva ON, Dixelius C, Meijer J, Priest FG (2004) Taxonomic characterization and plant colonizing abilities of some bacteria related to Bacillus amyloliquefaciens and Bacillus subtilis. FEMS Microbiol Ecol. 48:249-259.

Rothfuss F, Bender M, Conrad R (1997) Survival and activity of bacteria in a deep aged lake sediment (Lake Constance). Microb Ecol. 33:69-77.

Sureshbabu K, Amaresan N, Kumar K (2016) Amazing multiple function properties of plant growth promoting Rhizobacteria in the rhizosphere soil. Int J Curr Microbiol App Sci. 5: 661-683.

Tamura K, Stecher G, Peterson D, Filipski A, Kumar S (2013) MEGA6: Molecular evolutionary genetics analysis version 6.0. Mol Biol Evol. 30:2725-2729.

Tripti, Kumar A, Usmani Z, Kumar V, Anshumali (2017) Biochar and flyash inoculated with plant growth promoting rhizobacteria act as potential biofertilizer for luxuriant growth and yield of tomato plant J Environ Manage. 190:20-27.

Wellburn AR (1994) The spectral determination of chlorophylls $a$ and $b$ as well as total carotenoids using various solvents with spectrophotometers of different Resolution. J Plant Physiol. 144:307-313.

Wollum AG (1982) Cultural methods for soil microorganisms in: Page AL (ed) Methods of Soil Analysis Part 2-Chemical and Microbiological Properties, Agron Monogr. 9.2. ASA, SSSA, Madison, WI. 